\title{
SYSTEM OF CONTRACTS FOR THE DISPOSAL OF INTELLECTUAL PROPERTY RIGHTS
}

\section{Svitlana Mazurenko}

\section{INTRODUCTION}

One of the important issues in the study of intellectual property rights is the determination of the principles of regulation of relations with the disposal of economic rights to intellectual property.

Legislative provisions on the disposal of economic rights to intellectual property are regulated in the Central Committee of Ukraine, Civil Code of Ukraine and in special legislative acts. In the Civil Code of Ukraine, the regulation of contractual relations on the objects of intellectual property is devoted to Chapter 75 "Disposal of intellectual property rights" book 5 "Obligatory law". Chapter 16 of the Civil Code of Ukraine "Use of Intellectual Property Rights in Economic Activity" defines the principles of the use of intellectual property rights objects in economic relations. At the level of individual laws on the regulation of relations within individual intellectual property institutions, the provisions of the Laws of Ukraine "On Copyright and Related Rights" (Articles 31, 32), "On Protection of Rights to Inventions and Utility Models" (Art. 28), "On protection of rights to industrial designs", "On protection of rights to marks for goods and services" (Article 16), etc.

Intellectual property rights management contracts are a group of intellectual property agreements aimed at acquiring, changing or terminating economic rights for intellectual property objects ${ }^{1}$. The system of agreements on the creation of intellectual property results and the disposal of economic rights can be defined as the unity of an orderly set of civil legal agreements, which has as its systemic sign the purpose - the use of intellectual property rights and equivalents of individualization ${ }^{2}$. According to Art. 1107 of the

1 Iakubivskyi I. (2007) Dohovory shchodo rozporiadzhannia mainovymy pravamy intelektualnoi vlasnosti za zakonodavstvom Ukrainy [Agreements on the disposal of intellectual property rights under the legislation of Ukraine]. Pidpryiemnytstvo, hospodarstvo ta pravo, № 8, S. 16. [in Ukrainian].; Kryzhna V. (2004) Zahalna kharakterystyka dohovoriv shchodo rozporiadzhennia mainovymy pravamy intelektualnoi vlasnosti [General characteristics of the agreements on the disposal of intellectual property rights]. Pravo Ukrainy, № 9, S. 68. [in Ukrainian].

${ }^{2}$ Ruzakova O. (2008) Problemy postroeniya sistemy dogovorov o sozdanii rezultatov intellektualnoj deyatelnosti i rasporyazhenii isklyuchitelnymi pravami [Challenges in constructing the system of agreements on the creation of intellectual deliverables and exclusive rights]. YS. Avtorskoe pravo y smezhnye prava, № 6, S. 26. [in Russian]. 
Civil Code of Ukraine the disposal of intellectual property rights may be exercised on the basis of the following agreements: a license for the use of the object of intellectual property rights; license agreement; contract for the creation of a custom and use of the intellectual property object; an agreement on the transfer of exclusive intellectual property rights; another contract for the disposal of intellectual property rights.

The most common classification of intellectual property contracts by type of intellectual property is: copyright contracts; agreements on the use of related rights; patent-license agreements for objects of patent law; agreements on the use of the rights to the means of individualization of the participants of civil turnover, goods and services; agreements on the use of rights to the topology of integrated circuits; breeding rights agreements etc. Intellectual property rights management contracts are usually bilateral, consensual and repayable.

The essential terms of the contract for the disposal of intellectual property rights are:

- the subject matter of the contract (the object of intellectual property rights, the rights of use of which are transferred under the contract; the specific rights that are transferred; the ways of using the object, etc.);

- price (fee for the use of the intellectual property right object, which can be determined in the form of a flat-rate payment, initial (advance) payment, royalties, deductions from the proceeds received by the user; mutual charges on the wholesale price of the goods sold by the right holder and the user; advertising and promotion of goods and services in the relevant market; remuneration for specific services of the right holder, etc.);

- term (during which the contract, which does not exceed the term of the economic rights transferred under the contract), is valid.

The parties to the contract can be both natural persons who have reached the age of 14 (part 1 of Article 32 of the Civil Code of Ukraine), and legal entities (regardless of ownership and location). It should be noted that specific contractual arrangements impose special requirements on the status of the parties, such as: a commercial concession agreement requires that the parties be entities.

The form of contracts for the disposal of intellectual property rights is written. In the case of non-compliance with the written form, these contracts are void. However, the law may stipulate cases in which contracts for the disposal of intellectual property rights may be concluded verbally (Part 2 of Article 1107 of the Civil Code of Ukraine).

Contracts on the disposal of intellectual property rights are not subject to mandatory state registration, although they may be executed at the request of one of the parties in the manner prescribed by law. The absence of state 
registration does not affect the validity of the rights granted by a license or other contract and other rights to the relevant object of intellectual property rights, in particular the right to go to court for the protection of their rights (Part 1 of Article 1114 of the Civil Code of Ukraine).

The exception to this general rule applies to the contract for the transfer of exclusive intellectual property rights for the invention, utility model, industrial design, trademark, integrated circuit layout, plant variety or animal breed. In this case, the contract is valid only from the moment of its state registration in the State Intellectual Property Service of Ukraine. This conclusion follows from Part 2 of Art. 1114 of the Civil Code of Ukraine, according to which the fact of transfer of exclusive property rights of intellectual property, which in accordance with the Civil Code of Ukraine or other law are effective after their state registration, is subject to state registration ${ }^{3}$.

The direct procedure for the state registration of agreements on the disposal of intellectual property rights and other legal actions of state bodies for the implementation of the rules of law is governed by the Cabinet of Ministers of Ukraine Resolution "On Approval of the Procedure of Payment of Fees for Actions Related to the Protection of Intellectual Property Rights", "On State Registration of Copyright and Contracts Concerning the Author's Right to Work", "On Approval of the Procedure for Granting the Permission to You by the Cabinet of Ministers of Ukraine use of a patented invention (utility model) or registered topography of an integrated circuit "and acts of the Ministry of Education and Science of Ukraine adopted in due course. The latter include orders from the Ministry of Education and Science of Ukraine "On approval of the Instruction on the submission, review, publication and entry in the register of transfer of ownership of the invention (utility model) and the issue of a license to use the invention (utility model)"; "On approval of the Instruction on the submission, review, publication and entry in the register of information on the transfer of ownership of an industrial design and the issue of a license for the use of an industrial design"; "On approval of the Instruction on the submission, review, publication and entry in the register of information on the transfer of ownership of a mark for goods and services and the issue of a license to use the mark for goods and services"; "Approval of the Instruction on the Official Publication of a Statement of Readiness to Grant to Any Person the Permission to Use the Patented Invention (Utility Model) and Request for its Revocation", etc.

3 Kryzhna V. (2004) Zahalna kharakterystyka dohovoriv shchodo rozporiadzhennia mainovymy pravamy intelektualnoi vlasnosti [General characteristics of the agreements on the disposal of intellectual property rights]. Pravo Ukrainy, № 9, S. 68. [in Ukrainian]. 


\section{Licenses and License agreement}

Characterizing individual contractual structures in the field of intellectual property rights, we pay attention to licenses and license agreement.

Based on the content of Art. 1108 of the Civil Code of Ukraine can give the following definition of licenses in the field of intellectual property. A license is a written authorization granted by a person who has the exclusive right to authorize the use of an intellectual property object (licensor) to another person (licensee) for the use of that object in a particular limited area.

In general, the term "license" (from Latin licitus - authorization, law) is quite widely used in modern legislative terminology. In the context of intellectual property laws, licenses have traditionally been considered as a permit to use an intellectual property object. Thus, according to Art. 1 of the Law of Ukraine "On Protection of Rights to Inventions and Utility Models" license - permission of the patent owner (licensor) granted to another person (licensee) to use the invention (utility model) under certain conditions ${ }^{4}$.

With regard to license types, it should be noted that there are several criteria for classifying license types.

The criteria for classification are the licensee's right to grant licenses to others and the licensee's right to protect their exclusive rights against the unlawful acts of others.

In the former case, it is a simple (non-exclusive) license under which the licensee may grant the right to use the result of intellectual activity or the means of individualization to others. Licenses issued by a licensor to others must only provide for such use as is specified in the license agreement.

In the second case, it is an exclusive license under which the licensee is forbidden to issue licenses for the use of the result of intellectual activity or means of individualization to other persons. The essence of an exclusive license is the ability to use the facility in the absence of competitors. The right to prohibit all other persons from using the object still belongs to the right holder of the exclusive rights ${ }^{5}$.

Chapter 75 of the CC introduces the concept of a single license, which recognizes a license issued to one licensee and excludes the licensor from granting licenses to other persons for the use of the intellectual property right

4 Iakubivskyi I. (2007) Dohovory shchodo rozporiadzhannia mainovymy pravamy intelektualnoi vlasnosti za zakonodavstvom Ukrainy [Agreements on the disposal of intellectual property rights under the legislation of Ukraine]. Pidpryiemnytstvo, hospodarstvo ta pravo, № 8, S. 16. [in Ukrainian].

5 Naumova E. (2008) Dogovornoe regulirovanie oborota prav na intellektualnuyu sobstvennost [Contractual regulation of the circulation of intellectual property rights]. Yntellektualnaia sobstvennost. Avtorskoe pravo y smezhnye prava, № 6, S. 70-71. [in Russian]. 
in the field, which is limited by this license, but does not exclude the licensee's use of this license ect in the said field ${ }^{6}$.

The second classification of license agreements can be made depending on the will of the holder of exclusive rights to transfer the right to use the object of intellectual activity ${ }^{7}$.

First, it is a "voluntary license" under which the intellectual property right holder - the licensor voluntarily grants or undertakes to grant the other party the licensee the right to use the intellectual property object.

Second, it is a compulsory license where, at the request of the person concerned, the court, in the cases specified by law, may decide to grant that person the right to use the result of intellectual activity under certain conditions, that is, against the will of the owner of intellectual property rights ${ }^{8}$.

The third classification is in accordance with the method of protection of the object of the license agreement. License agreements are divided into: patent; patent-free; complex.

Patent license agreements are contracts for the use of intellectual property that are protected by appropriate security documents: patents or certificates.

Patent-free licenses include licensing agreements that grant the right to use scientific and technical achievements that do not have legal protection, production experience, confidential information of a managerial, commercial, organizational nature, ie production secrets ("know-how") and decisions on which applications for legal protection were filed ${ }^{9}$.

A special variety of patent and non-patent licenses should include license exchange agreements. This type of "cross-license" ("cross-license") is widespread in practice for a variety of reasons. On the one hand, later patents are often dependent on previously issued ones and cannot be used without the acquisition of a patent protected prototype. In its turn, the owner of this prototype is interested in purchasing more advanced technical solutions. As a result, licenses are exchanged between owners of related patents. On the other hand, competing firms that are interested in improving the technical and

${ }^{6}$ Kuvyrkova A.Yu. (2009) Licenzionnyj dogovor o predostavlenii prava ispolzovaniya obekta intellektualnyh smezhnyh prav [License agreement on granting the right to use the object of intellectual related rights]. Zakonodatelstvo, № 5, S. 58. [in Russian].

${ }^{7}$ Melnyk O. (2003) Dohovory u sferi intelektualnoi vlasnosti za novym Tsyvilnym kodeksom Ukrainy [Intellectual property contracts under the new Civil Code of Ukraine]. Pidpryiemnytstvo, hospodarstvo ta pravo, № 9, S. 8. [in Ukrainian].

8 Naumova E. (2008) Dogovornoe regulirovanie oborota prav na intellektualnuyu sobstvennost [Contractual regulation of the circulation of intellectual property rights]. Yntellektualnaia sobstvennost. Avtorskoe pravo y smezhnye prava, № 6, S. 70-71. [in Russian].

${ }^{9}$ Dobrynina H. (2007) Litsenziina diialnist shchodo obiektiv prava intelektualnoi vlasnosti [Licensing activity towards intellectual property objects]. Spravochnik ekonomista, № 3. S. 5. [in Ukrainian]. 
economic level of their products are more likely to use licenses than sell them without sharing any secrets ${ }^{10}$.

Under a comprehensive license agreement, a licensee obtains the right to use several intellectual property objects, some of which have legal protection and the other does not.

Depending on the object, the following license agreements are distinguished: copyright; about the grant of related rights; granting an invention, utility model or industrial design right; on the granting of trademark rights; on granting rights to the topology of integrated circuits; about granting breeding achievement rights ${ }^{11}$.

As a kind of license agreements can be considered sub-license agreement, the provisions of which are contained in part 2 of Art. 1109 of the Central Committee of Ukraine. Under this agreement, the licensee grants permission to use the intellectual property object to another person (sub-licensee). Sublicense agreement is possible only in cases, which are expressly stipulated in the license agreement between the licensee and the licensee. However, since the sublicensee is not in direct contractual relationship with the licensee, the licensee is liable to the licensee for the actions of the sublicensee, unless otherwise stipulated by the license agreement.

The Central Committee of Ukraine permits the possibility of issuing a license without concluding a license agreement. In Art. 1107 license and license agreement are defined as separate types of contracts for the disposal of intellectual property rights. However, the license itself is a one-sided transaction and cannot be regarded as a type of contract ${ }^{12}$.

Therefore, it is inappropriate to include it alongside a license agreement as a type of intellectual property rights management agreement. Assignment of a license to agreements on the disposal of intellectual property rights in Art. 1107 of the Central Committee of Ukraine is wrong ${ }^{13}$.

10 Levchenko D. (2006) Aspekty licenzionnyh dogovorov. Otnositelno licenzionnyh dogovorov o peredache prav na obekty intellektualnoj sobstvennosti [Aspects of license agreements. On license agreements on the assignment of intellectual property rights]. Yurydycheskaia praktyka, № 11, S. 22. [in Russian].

${ }_{11}$ Ruzakova O. (2008) Problemy postroeniya sistemy dogovorov o sozdanii rezultatov intellektualnoj deyatelnosti i rasporyazhenii isklyuchitelnymi pravami [Challenges in constructing the system of agreements on the creation of intellectual deliverables and exclusive rights]. YS. Avtorskoe pravo y smezhnye prava, № 6, S. 26. [in Russian].

12 Kryzhna V. (2004) Zahalna kharakterystyka dohovoriv shchodo rozporiadzhennia mainovymy pravamy intelektualnoi vlasnosti [General characteristics of the agreements on the disposal of intellectual property rights]. Pravo Ukrainy, № 9, S. 68. [in Ukrainian].

13 Iakubivskyi I. (2007) Dohovory shchodo rozporiadzhannia mainovymy pravamy intelektualnoi vlasnosti za zakonodavstvom Ukrainy [Agreements on the disposal of intellectual property rights under the legislation of Ukraine]. Pidpryiemnytstvo, hospodarstvo ta pravo, № 8, S. 16. [in Ukrainian]. 
Special laws, unlike the Central Committee of Ukraine (for example, Article 32 of the Law of Ukraine "On Copyright and Related Rights", Article 28 of the Law of Ukraine "On Protection of Rights to Inventions and Utility Models" Article 20 of the Law of Ukraine "On Protection of Rights to industrial designs", Article 16 of the Law of Ukraine" On Protection of Rights to Marks for Goods and Services", Article 40 of the Law of Ukraine" On Protection of Rights to Varieties of Plants", Article 16 of the Law of Ukraine" On Protection of Rights for Topographies integrated circuits") proceed from the fact that a license is always issued on the basis of a license agreement. Apparently, this approach is more grounded and correct. It is difficult to imagine the option of granting an entity that owns intellectual property rights a license to use the object without entering into a contract. It is the license agreement in this case that is the basis for granting the permit (issuing a license) and, at the same time, a means of determining the conditions for granting such a license.

Referring to the characteristics of the license agreement, it should be noted that it occupies an important place among the agreements on the disposal of intellectual property rights. According to Art. 1109 of the Civil Code of Ukraine under a license agreement one party (the licensee) grants the other party (the licensee) permission to use the object of intellectual property (license) on terms determined by mutual agreement of the parties, taking into account the requirements of the Central Committee of Ukraine and other law.

In the scientific literature, the following specific features of the license agreement are distinguished: the intellectual product offered for transfer under the contract is intangible; the licensee acquires the right to use the intellectual property rights defined in the contract by the contract; tangible objects, if transferred under a license agreement, are only carriers of information that is the object of intellectual property; the core element of the license object - the exclusive intellectual property right does not pass to the licensee, but is only granted a temporary right to use the object of that right; the patent holder retains proprietary rights to the intellectual property when granting the license ${ }^{14}$.

A license agreement is considered to have been concluded if the parties have agreed to the essential terms (ie, those conditions which are recognized as essential by law or necessary for contracts of this type), ie such agreement is legally consensual ${ }^{15}$. In addition, a mandatory condition for the validity of a

14 Bazylevych V.D. (2008) Intelektualna vlasnist: pidruchnyk [Intellectual property: a textbook]. K. : Znannia, S. 221. [in Ukrainian]

${ }^{15}$ Kyryliuk A.V. (2008) Litsenziinyi dohovir na vykorystannia literaturnykh tvoriv: poniattia, umovy, forma [License agreements on the use of literary writings: concept, conditions, form]. Aktualni problemy derzhavy i prava, № 41, S. 192. [in Ukrainian]. 
license agreement is to conclude it in writing, since failure to comply with the written form results in the nullity of such agreement (Part 2 of Article 1107 of the Civil Code of Ukraine). Please note that the license agreement may not be the right to use an intellectual property object that was not valid at the time the contract was concluded.

Based on the provisions of Part 1 of Art. 638 and Part 3 of Art. 1109 of the Civil Code of Ukraine to the essential terms of the license agreement belong to the subject of the contract; type of license; scope of the intellectual property right object (specific rights conferred by the contract, ways of using the said object, territory and terms to which the rights are granted, etc.), size, procedure and payment terms for the use of the intellectual property right object property.

The parties to the license agreement must clearly identify the possible extent of the use of the intellectual property object, the possibility of transferring the intellectual property object to third parties, maintaining the confidentiality of the content of the license agreement, the procedure and amount of payment.

It should be noted that the Central Committee of Ukraine has expanded the scope of the license agreement. If in the special legislation on intellectual property the copyright contract in the field of copyright and the license agreement in the field of industrial property differ, then the Central Committee of Ukraine establishes a universal design of the license agreement, which applies to both the objects of copyright and the objects of industrial property.

The primary legal purpose of this agreement is to grant a license (license) for the use of a specific intellectual property right. The license agreement is one of the options for obtaining a license for the use of intellectual property rights (Part 2 of Article 1108 of the Civil Code of Ukraine). Therefore, the provisions of Art. 1108 of the Civil Code of Ukraine on licenses for the use of intellectual property rights should also be applied to the license agreements ${ }^{16}$.

Typical contracts have traditionally played an important role in the legal regulation of contractual relations in the field of intellectual property. In the Central Committee of Ukraine the provisions on standard license agreements are contained in Art. 1111. The Institute for Standard License Agreements is intended to provide enhanced protection of the interests of the creator of the intellectual property object in the contractual relationship. The right to approve standard license agreements in accordance with Part 1 of Art. 1111 of

16 Kossak V.M., Yakubivskyi I.Ie. (2007) Pravo intelektualnoi vlasnosti: pidruchnyk [Intellectual property law: a textbook]. K. : Istyna, S. 158-159. [in Ukrainian] 
the Central Committee of Ukraine was provided to authorized agencies and creative unions.

The license agreement may, in the cases provided for by law, entail the conclusion of a sub-license agreement whereby the licensee grants a sublicense to another (sub-licensee) for the use of the intellectual property object. In this case, the licensee shall be liable to the licensee for the actions of the sub-licensee, unless otherwise stipulated by the license agreement.

\section{The contract on the creation and use of the intellectual property object}

The contract on the creation and use of the intellectual property object plays a special role in the mechanism of civil law regulation of copyright, creating the preconditions for their dynamics. Relationships for the creation of a copyright object can be described as organizational relations, namely preordering, since the contractual contractual relations of the copyright order are the legal connection of the parties that arises before the creation of the copyright object. Assuming that copyright regulates relationships that arise in the process of using a work already created, then before the creation of the work itself, the party to the copyright contract can only be called by the author provisionally, correctly call her the person who is obliged to create the work ${ }^{17}$.

The essential terms of the contract are: the subject of the contract, the term of creation of the object of intellectual property rights, methods and conditions of its use, the price.

When considering the content of the copyright contract, it is proposed to split it into two parts. The first part of the contract consists of the conditions aimed at regulating the relations that arise from the author's creation of his work. The second part of the conditions consists of the conditions inherent in the copyright agreement under which the finished work is transmitted ${ }^{18}$.

The first part of the contract includes the terms of the subject of the contract and its description, the rights and obligations of the parties, the goods of the contract, responsibility for breach of contract.

Attention should be paid to the specifics of the copyright contract. It is concluded at a time when the intellectual property object does not yet exist, and due consideration should be given to the characterization of the subject matter of this agreement and the definition of its features. As a rule, objects of copyright and related rights are the subject of the contract because the creation

${ }^{17}$ Sorokyna L.V. (2008) Otgranichenie avtorskogo dogovora zakaza ot smezhnyh dogovorov [Delimitation of commissioning agreement from related agreements]. Rossyiskyi yurydycheskyi zhurnal, № 5, S. 204. [in Russian].

${ }^{18}$ Zavalna Zh. (2002) Osoblyvosti dohovoru zamovlennia v avtorskomu pravi [Special aspects of an ordering agreement in copyright law]. Pidpryiemnytstvo, hospodarstvo i pravo, № 12, S. 15. [in Ukrainian]. 
of an industrial property right occurs under the contract of research or development and technological works.

When characterizing the subject of the contract, the following should be noted.

The more specific the work to be created, the less likely it is that disputes arise over the parties' performance of their contractual obligations. Such features may include, in particular, the volume, type, genre, purpose, working title of the future work, the scope of its possible use, and, if appropriate, a summary of the work (plan, synopsis, etc.), its intended content. etc. The work can be created by the author and sent to the customer on a physical medium or in another form (for example, using computer equipment and transferring the results of works on the digital network $)^{19}$.

In some cases, it is useful to add drafts to the contract, a description of stylistic features, a list of actors, character descriptions, and more. This will additionally protect the customer from cases when the author transfers the rights to the created work to other persons, and will help the author to resolve disputes in case of refusal of the customer to accept the work created by the copyright contract.

Based on the content of Article 1109 of the Civil Code of Ukraine and Articles 31-33 of the Law of Ukraine "On Copyright and Related Rights", copyrights that are not valid at the time of the conclusion of the relevant contract, in particular, have not been subject to transfer (or enjoyment). at the time of the conclusion of the contract (the rights to the undeveloped object). The only exception is the contract for the creation of a custom and use of the copyright object (Article 1112 of the Civil Code of Ukraine). According to its terms, only if there are clear requirements for a work that has not yet been created (ordered), the parties have the right to determine the transfer of copyright to such object or the procedure for its use in the future.

In light of the above, the condition of a comprehensive agreement for the transfer (or use) of rights to works that do not already exist and which will be created by a party in the future in the performance of its contractual obligations without a detailed description of the requirements for such works, does not correspond to the content of the legislation and may to be declared null and void.

In order to avoid the specified risk in the agreement, the parties may, for example, provide for a suspensive condition that the provision of the contract

${ }^{19}$ Blyznets Y.A., Leontev K.B. (2009) Avtorskoe pravo i smezhnye prava: uchebnik: uchebnyk [Copyright and related rights: a textbook]. M. : Prospekt, 2009. S. 124-125. [in Russian] 
for the transfer of rights to the work not yet created at the time of the conclusion of the contract enters into force from the moment of creation of such work ${ }^{20}$.

Among the rights and obligations of the parties to the copyright contract, the following questions must be addressed: whether the author should work alone or may seek the assistance of others; whether the author may, during the term of the agreement, carry out other orders of third parties for the creation of intellectual property objects; whether the author can share some of the created object or make it known to third parties; to determine the terms and stages of acceptance of the work; the possibility of returning the work with the customer's comments for the author's revision; terms of making changes to the work, the possibility of transferring the right to use the work to third parties; order of acceptance of the order; stages of payment, etc.

The final terms of the first part of the contract are the responsibility of the author and the customer for the failure or improper performance of the obligations to create and accept the commissioned work. Such conditions may be: the responsibility of the author for the late submission of the work, the responsibility of the customer for the late acceptance of the work, etc. In practice, it is suggested in the form of responsibility for the customer to apply an advance to be left to the author, or full payment of the fee for the late acceptance of the work or for non-acceptance of the work. Penalties may be applied as a percentage of the fee ${ }^{21}$.

It is also proposed to charge the author with a penalty if this is stipulated in the contract. However, the amount of amounts charged to the author may not exceed the amount of actual damages caused by the author's failure to perform or improper performance of the contract ${ }^{22}$.

When considering the allocation of intellectual property rights to a custom-made object, you should refer to the content of Art. 430 of the Central Committee of Ukraine.

According to Part 1 of Art. 430 of the Civil Code of Ukraine provides that the personal non-proprietary intellectual property rights of the custom-made object belong to the creator of that object. In cases provided for by law,

20 Mamunia A. (2008) «Avtorstvo» v kommercheskom dogovore. Rasporyazhenie imushestvennymi pravami avtora v ramkah kompleksnogo soglasheniya ["Authorship" in the commercial contract. Disposal of property rights of the author under the framework of a complex agreement]. Yurydycheskaia praktyka, № 21 (543) ot 20.05.08 h. // http://yurpractika.com. [in Russian].

${ }^{21}$ Zavalna Zh. (2002) Osoblyvosti dohovoru zamovlennia v avtorskomu pravi [Special aspects of an ordering agreement in copyright law]. Pidpryiemnytstvo, hospodarstvo i pravo, № 12, S. 15. [in Ukrainian].

${ }^{22}$ Blyznets Y.A., Leontev K.B. (2009) Avtorskoe pravo i smezhnye prava: uchebnik: uchebnyk [Copyright and related rights: a textbook]. M. : Prospekt, 2009. S. 127. [in Russian] 
individual personal non-proprietary intellectual property rights in such an entity may belong to the customer.

This section of the article establishes that in the cases provided for by law, individual personal non-proprietary intellectual property rights in such an object may belong to the customer. In our view, this provision is contrary to Art. 266, 269, 438 of the Civil Code of Ukraine, because only the author may own personal non-property rights to the object of intellectual property rights. In addition, it should be noted that personal non-property rights are inalienable, absolute in nature, and belong to the author as long as the author exists as a subject.

Since the law did not provide either a list of personal non-proprietary intellectual property rights that may belong to the customer, or the conditions for the acquisition of such rights, in applying Art. 430 of the Civil Code of Ukraine should be based on the nature of one or another personal nonproprietary intellectual property right. Therefore, it can be concluded that the customer may have the right to ensure the integrity of the work, to counteract any encroachment on the work. In order to avoid in practice difficulties in applying Art. 430 of the Civil Code of Ukraine it is necessary for the legislator to clearly define under what conditions and what personal nonproperty intellectual property rights may belong to the customer ${ }^{23}$.

Part two of Article 430 of the Civil Code of Ukraine regulates the property relations between the customer and the contractor and establishes a rule on the commonality of ownership of intellectual property rights to the object created by order. This provision is dispositive and enables the parties to independently decide on the distribution of intellectual property rights.

\section{The contract for the creation and use of work}

Considering the contract for the creation and use of official work, it should be noted that the labor relations between employers and authors of the results of creative activities are different from those of other employees in that personal rights are granted to authors of the results of creative activities. Creators of any other results of non-creative activity do not have personal non-proprietary rights to the objects that are created. The difference between creative and any other activity that does not lead to the creation of intellectual property objects, has led to the formation of professional creative results ${ }^{24}$.

${ }^{23}$ Paladii M.V., Myronenko N.M., Zharov V.O. (etc.) (2006) Pravo intelektualnoi vlasnosti: naukovo-praktychnyi komentar do Tsyvilnoho kodeksu Ukrainy [Intellectual property right : scientific and practical commentary to the Civil Code of Ukraine]. K. : Parlamentske vydavnytstvo, S. 72. [in Ukrainian]

${ }^{24}$ Sudarykov S.A. (2009) Avtorskoe pravo: uchebnik [Copyright: a textbook]. M. : Prospekt, S. 73. [in Russian] 
With regard to the employment contract, copyright theory has long been in dispute as to what kind of legal relationship arises when creating copyright objects in connection with the fulfillment of the terms of the employment contract - single copyright or separate labor and copyright. This question was resolved in favor of the second point of view. When creating and using official works, there are both employment and copyright relationships. This position was expressed by BS Antimonov and EA Fleischitz, and also rightly supported later by V. O. Kalyatin ${ }^{25}$.

You can talk about the existence of a comprehensive agreement in the case where:

- the contract for the creation and use of official works is a set of two independent obligations: labor (in the general order of creation of the work) and copyright (in the order of disposal of economic rights to the work);

- the existence of a single contract for the creation and use of official work is an admission of contractual technique, which is aimed at simplifying the contractual process. In fact, it is possible to conclude two separate contracts labor and copyright, by which in their totality would regulate the relations on the creation and use of official work. This confirms the fact that labor and copyright obligations may exist autonomously. However, combining them into a single contract is essential. When concluding such an agreement, the peculiarities of official creativity - its copyright and labor aspects - are taken into account ${ }^{26}$.

Part one of Art. 429 of the Civil Code of Ukraine regulates the procedure for the acquisition of intellectual property rights on "service" objects of intellectual property rights, solely on the basis of their direct connection with the employment contract. This article of the Central Committee of Ukraine defines a special legal regime for an object of intellectual property right, which is created within a certain period of time, that is, within the term of a duly executed employment contract. It is this fact that is decisive for establishing an appropriate legal regime for the regulation of intellectual property rights in respect of the objects covered by this CC. The second legal fact, the existence of which is obligatory for the application of part one of Art. 429 of the Criminal Code of Ukraine, is that the result of intellectual,

${ }^{25}$ Antymonov B.S., Fleishyts E.A. (1957) Avtorskoe pravo [Copyright]. M.: Hosiuryzdat, S. 64; Kaliatyn V.O. (2000) Intellektualnaya sobstvennost (isklyuchitelnye prava): uchebnik dlya vuzov [Intellectual property (exclusive rights): a textbook for higher education]. M.: NORMA, S. 165. [in Russian]

${ }^{26}$ Zhylynkova E. (2009) Klassifikaciya dogovorov v sfere realizacii imushestvennyh prav na obekty avtorskogo prava na Ukraine [Contracts classification in the area of intellectual property rights in Ukraine]. Yntellektualnaia sobstvennost. Avtorskoe pravo y smezhnye prava, № 1, S. 48. [in Russian]. 
creative activity must be directly related to the performance of work functions (work duties) of the employee. There are no other indications that could affect the regulation of relations regarding the creation of an intellectual property object and the acquisition of the right to it in connection with the performance of an employment contract. Moreover, in Article 429 of the Civil Code of Ukraine, the legislator focused not on identifying the features of intellectual property rights created under certain conditions but on the subjective composition of the legal relationship ${ }^{27}$.

It is believed that the works created by the employee during working hours are automatically official in the workplace. However, in order for the work to become official, you must:

- Before the beginning of its creation, send to the employee a written job assignment, possibly in the form of a business note, to create a certain work, part of it (in the case of co-authorship, revision, etc.). In the task it is necessary to describe as much as possible the purpose, technical requirements for the work being created, in order that in the future no one would have any doubt that it is for this, the already created work was sent a task from the employer to the author. In addition, the employer is advised to submit such a task to the employee's schedule;

- enter into an employment contract and / or civil contract detailing the assignments, technical requirements for the work created and other specifications regarding the work $^{28}$.

In determining whether a work is created as a service, as Khokhlov V.A. points out, the following provisions should be considered:

- only the work whose creation came directly into the employee's job functions can be considered official;

- the case-law is based on the fact that the employer must prove the official nature of the work; the job title itself, the workplace do not give grounds for qualifying the work as an official;

- does not affect the recognition of the work official time and place of its creation (in practice, known cases where the work was recognized as official, although created by employees not at work, but at home);

${ }^{27}$ Paladii M.V., Myronenko N.M., Zharov V.O. (etc.) (2006) Pravo intelektualnoi vlasnosti: naukovo-praktychnyi komentar do Tsyvilnoho kodeksu Ukrainy [Intellectual property right : scientific and practical commentary to the Civil Code of Ukraine]. K. : Parlamentske vydavnytstvo, 2006. S. 62. [in Ukrainian]

${ }^{28}$ Danevych B. (2009) Raspredelenie prav na avtorstvo. Problemnye aspekty raspredeleniya prav intellektualnoj sobstvennosti mezhdu rabotnikom i rabotodatelem [Allocation of author rights. Challenges of allocation of intellectual property rights between employee and employer]. Yurydycheskaia praktyka, 2009. № 39 (61) ot 29.09.09 h. // http://yurpractika.com. [in Russian]. 
- the fact of using the materials or equipment of the organization where the author works does not lead to the definition of the work as official;

- the legal regime of an official work does not change in the case of an employee being dismissed, it also does not matter whether the employee is a full-time employee or a part-time employee;

- the official nature of the work does not change in case the employer additionally provided or, conversely, did not provide with any sums of money (increased wages, bonuses, etc.);

- the notion of "task", which as a result of clarification of the essence of the necessary actions, their actualization and localization, is capable of answering the questions in the disputed cases is essential for the correct qualification, and is not a job task. However, the mere issuance of a task outside the work function, even if performed, does not give grounds for recognition of the work as official.

The need to establish the official nature of the work is explained by the special division of rights and responsibilities between the employer and the employee in this case ${ }^{29}$.

If the primary subject of copyright (the bearer of personal non-property and economic rights of intellectual property) is the author of the work (part one of Art. 435 of the Civil Code of Ukraine), his copyrights arise at the moment of creation of the work (part of Art. 437 of Civil Code of Ukraine), and in situation, which is provided for in part one of Art. 429 of the Civil Code of Ukraine, the moment when the employee's intellectual property rights arise is determined not by the fact of creation of the object of intellectual property right, but by the fact of notification by the employee of the employer of the creation of such object. From now on, based on the content of part two of Art. 429 of the Civil Code of Ukraine parties to the employment contract - the employee and the employer must regulate their relations on the intellectual property right to the object of intellectual property rights, created in connection with the performance of the employment contract, in a civil legal way, ie contract. There is no other procedure for transferring an employee's intellectual property rights to an employer by law. From the literal interpretation of the norm of Article 429 of the Civil Code of Ukraine, it follows that the fact of creation of a work by an employee is a consequence of fulfilling their official duties, and the creation of this particular result of intellectual, creative activity is caused not by the personal creative abilities of the employee, but by job requirements, respectively, the

${ }^{29}$ Khokhlov V.A. (2008) Avtorskoe pravo: zakonodatelstvo, teoriya, praktika [Copyright: legislation, theory, practice]. M. : «Horodets», S. 76-77. [in Russian] 
work is a natural result production activity of the employee as any natural person occupying this position ${ }^{30}$.

The intellectual property rights of the object created in connection with the performance of the employment contract belong to the employee who created the object and the legal or natural person where or in which it works. This provision is dispositive and, with the agreement of the parties, may be stipulated otherwise in the contract.

There are two opposing views on the issue of remuneration for authors of official works, which are based on the question of what the author should receive remuneration for: for the creation of the work or for its use. According to the first, royalties are paid to the author in the form of wages. Supporters of the other believe that wages are only remuneration for scientific and creative work, not for industrial or commercial use of the work. In this case, there should be a separate fee, depending on the particular use of the work. The reward is the sense of existence of the copyright institute itself, the main object of the authors' requirements. National law of different countries generally recognizes the right of the author of a work of work to receive, in addition to wages, a separate royalties due to the use of the results of his creative work $^{31}$.

Under the agreement on the transfer of exclusive intellectual property rights, one party (a person who has exclusive rights) transfers to the other party, in part or in full, these rights in accordance with the law and under the terms and conditions specified in the contract (Part 1 of Article 1113 of the Civil Code of Ukraine).

The essential terms of a contract for the transfer of exclusive intellectual property rights are: the term of the contract, the ways of using the work, the territory to which the transferable right extends, the amount and procedure of payment of royalties, as well as other conditions on which at the request of one of the parties to be agreed.

However, the terms of the contract for the transfer of exclusive intellectual property rights that impair the position of the creator of the respective object or its heirs in comparison with the situation stipulated by the Civil Code of Ukraine or other law, and also limit the creator's right to create other objects, are null and void.

${ }^{30}$ Paladii M.V., Myronenko N.M., Zharov V.O. (etc.) (2006) Pravo intelektualnoi vlasnosti: naukovo-praktychnyi komentar do Tsyvilnoho kodeksu Ukrainy [Intellectual property right : scientific and practical commentary to the Civil Code of Ukraine]. K. : Parlamentske vydavnytstvo, 2006. S. 63. [in Ukrainian]

${ }^{31}$ Bondarenko S.V. (2008) Avtorske pravo ta sumizhni prava [Copyrigh and related rights]. K. : In-t intel. vlasn. i prava, S. 71. [in Russian] 


\section{The contract of commercial concession (Franchising)}

According to Art. 1115 of the Civil Code of Ukraine under the contract of commercial concession one party (right holder) undertakes to grant to the other party (user) for payment the right of use according to its requirements by a complex of rights belonging to that party for the purpose of production and / or sale of a certain type of goods and (or) services.

In concluding a commercial concession agreement, in addition to the provisions of the Civil Code of Ukraine, Civil Code of Ukraine, the provisions of special normative acts governing the relations in the sphere of turnover and protection of rights to certain types of intellectual property objects should be taken into account.

The essential features of a commercial concession are that under a commercial concession agreement, the right holder grants the user the right to use for a fee a set of exclusive intellectual property rights to promote the promotion of goods (services) in a particular market. The requirements stipulated by law and which can be included in the contract include instructions on the territory of use, the sphere of civil turnover, the right to enter into a commercial sub-concession agreement, the obligation to carry out state registration of the contract, the transmission of technical and commercial documentation, quality control of goods, etc.

Franchising in practice is implemented in various forms. It is customary to classify by species by different criteria. Most often in the legal literature, franchising is classified by type according to the functions it performs. In the Franchise Guide, WIPO is divided into three types of franchising:

- franchise for processing (production);

- franchise for services (service);

- Wholesale franchise (distribution).

The basis of this division is historically the way and the amount of activity that the user performs under the franchise stipulated in the commercial concession agreement ${ }^{32}$.

In other words, the basis of the division is the amount of rights regarding possible activities that can be performed under a commercial concession agreement by the user ${ }^{33}$, depending on the nature of the economic relations ${ }^{34}$.

Production franchising is widely represented in the production of soft drinks (Coca-Cola, Pepsi and Seven-Up). It should be noted that using this type of

${ }^{32}$ VOIS (1995) Rukovodstvo po franshize [Franchising guide]. Zheneva: VOIS, 1995. S. 15. [in Russian]

${ }^{33}$ Biloshytskyi S. (2008) Modeli dohovoriv komertsiinoi kontsesii [Models of franchise agreement]. Pravovyi tyzhden, № 13 (86) vid 25.03.2008 r., S. 8. [in Ukrainian].

${ }^{34}$ Klymenko A. (2004) Dogovor franchajzinga - analiz soderzhaniya [Franchise agreement content analysis]. Nalohy y bukhhalterskyi uchët, № 74 (736) ot 13.09.2004, S. 25. [in Russian]. 
commercial concession agreement, the user carries out the entire production cycle of manufacturing the final product under the trademark of the right holder. In this case, the right holder provides the user with the necessary ingredients, ingredients, equipment, and the other party, ie the user, produces the final product under the trademark and has the right to distribute it to consumers ${ }^{35}$.

When franchising services are provided, technology is provided to provide services to hotels (Holiday Inn, Hilton, Marriotvn), peters, fast food establishments (McDonald's, Pizza Hut, etc.), branded car service stations, gas stations, insurance companies, banks, etc ${ }^{36}$.

Business franchise ("package - franchise") ${ }^{37}$ is a method of doing business in such a way that the right holder benefits from the rapid growth of the franchise network at limited costs and risk, and the user - from the right to use a proven commercial system.

When entering into such an agreement, the right holder grants the right of use to private individuals or legal entities to open shops, supermarkets for sale to buyers of a set of products or services under the rightholder's name and trademark. In Ukraine, a business concession is used, for example, "Silpo"38.

\section{CONCLUSIONS}

Under a commodity (trade) franchise agreement, the user purchases the right of the parent company to sell goods with its trademark (in fact, it is a right to sell goods on behalf of the manufacturer). Official car dealers can be cited as an example of such a commercial concession. Merchant Franchising (Merchant Franchising) is a way of doing business whereby a copyright holder who manufactures a product grants the right to sell its products to the user, with the obligatory use of the trademark for the goods and services of the right holder and in a clearly defined franchise territory ${ }^{39}$.

The second classification of franchising is related to internationalization of business. Depending on the method of organization, structure and relationships of the franchise network distinguish the following models of franchising ${ }^{40}$ :

${ }^{35}$ Biloshytskyi S. (2008) Modeli dohovoriv komertsiinoi kontsesii [Models of franchise agreement]. Pravovyi tyzhden, № 13 (86) vid 25.03.2008 r., S. 8. [in Ukrainian].

${ }^{36}$ Sudarykov S.A. (2009) Sudarikov S.A. Pravo intellektualnoj sobstvennosti: uchebnik [Intellectual property right: a textbook]. M. : Prospekt, 2009. S. 284. [in Russian]

${ }^{37}$ Leheida E. (1996) Franchaizynh. Novaia forma orhanyzatsyy byznesa [Franchising. A new form of business organization]. Byznes - ynform, № 20, S. 32. [in Russian].

${ }^{38}$ Biloshytskyi S. (2008) Modeli dohovoriv komertsiinoi kontsesii [Models of franchise agreement]. Pravovyi tyzhden, № 13 (86) vid 25.03.2008 r., S. 8. [in Ukrainian].

39 Biloshytskyi S. (2008) Modeli dohovoriv komertsiinoi kontsesii [Models of franchise agreement]. Pravovyi tyzhden, № 13 (86) vid 25.03.2008 r., S. 8. [in Ukrainian].

${ }^{40}$ VOIS (1995) Rukovodstvo po franshize [Franchising guide]. Zheneva: VOIS, 1995. S. 50. [in Russian]; Leheida E. (1996) Franchaizynh. Novaia forma orhanyzatsyy byznesa [Franchising. A new form of business organization]. Byznes - ynform, № 20, S. 32. [in Russian]. 
- direct franchising (classic franchising, regional commercial concession agreement) - the contract is concluded between the right holder located in one country and the user located in another country. This scheme is possible if the countries are geographically nearby and they have related culture and customs. In this case, the right holder controls the business of the user. The classic model, also called direct franchising, involves a direct relationship between the right holder and the user. The rights holder himself searches for the user's applications, negotiates with them and enters into contracts. The direct franchise model is most effective when the right holder and the user are in the same state. Franchising network in direct franchising can be built on two basic principles: the conclusion of simple contracts between the right holder and one or more users to open one franchise point to each user (single element franchise), concluding with one or more users franchisee to develop contracts for the development of franchise. Most often, combinations of these methods are used in one network.

- indirect franchising (developing franchising, that is, a development concession agreement) - this type is used when countries are geographically distant from one another and there are significant differences in culture, customs, language barrier. Structural elements of the franchising system are subsidiaries, branches, joint ventures. In this case, the established businesses ensure the adaptation of the franchise system to the local conditions, as well as provide direct communication between the right holder and the user. An example of this type is the creation of a McDonald's restaurant chain in Ukraine. The development contract provides for the opening by the user of several franchise points in the specified contract area and for a specified period. In this case, a separate franchise agreement is signed for each new point. In other words, the user is obliged to open the number of franchise points discussed, and the right holder guarantees to conclude an appropriate number of franchise agreements with him.

- master franchising (sub-franchising, sub-concession) - in this case the contract is concluded for the purpose of organization of franchising enterprises, ie the scheme of relations can be displayed in the following way: right holder - main user - user. The disadvantage of such a system is the inability to effectively control user activity.

The division of such models is based on the emergence of new, additional parties to the commercial concession agreements and, as a result, related features in the rights and obligations of the parties that are determined during the conclusion of the commercial concession agreement. In new models, in addition to the already mentioned subjects of the commercial concession 
agreement, such as the right holder and the user, there are additional parties: the main user, the sub-user, the developing user $^{41}$.

A commercial concession contract can be based on the combination of several models and combine, for example, a territorial concession and a developing concession.

\section{SUMMARY}

For the person who created the result of intellectual activity (intellectual product), the conclusion of the contract is one of the legal forms of realization of rights to the results of intellectual activity. Intellectual property performance treaties have a specific nature that sets them apart from other treaties. The results of intellectual activity are intangible and can be embodied in the material medium. Intellectual property rights are limited in time and space. In addition, the results of intellectual activity can be used not only by the entity but also by others. That is, the right holder can not only use the intellectual product independently, but at the same time give permission for its use to other interested persons. Intellectual property performance contracts are concluded only for those intellectual products that are recognized by law enforcement as required by law.

\section{REFERENCES}

1. Iakubivskyi I. (2007) Dohovory shchodo rozporiadzhannia mainovymy pravamy intelektualnoi vlasnosti za zakonodavstvom Ukrainy [Agreements on the disposal of intellectual property rights under the legislation of Ukraine]. Pidpryiemnytstvo, hospodarstvo ta pravo, № 8, S. 16. [in Ukrainian].

2. Kryzhna V. (2004) Zahalna kharakterystyka dohovoriv shchodo rozporiadzhennia mainovymy pravamy intelektualnoi vlasnosti [General characteristics of the agreements on the disposal of intellectual property rights]. Pravo Ukrainy, № 9, S. 68. [in Ukrainian].

3. Ruzakova O. (2008) Problemy postroeniya sistemy dogovorov o sozdanii rezultatov intellektualnoj deyatelnosti i rasporyazhenii isklyuchitelnymi pravami [Challenges in constructing the system of agreements on the creation of intellectual deliverables and exclusive rights]. YS. Avtorskoe pravo y smezhnye prava, № 6, S. 26. [in Russian].

4. Naumova E. (2008) Dogovornoe regulirovanie oborota prav na intellektualnuyu sobstvennost [Contractual regulation of the circulation of

${ }^{41}$ Biloshytskyi S. (2008) Modeli dohovoriv komertsiinoi kontsesii [Models of franchise agreement]. Pravovyi tyzhden, № 13 (86) vid 25.03.2008 r., S. 8. [in Ukrainian]. 
intellectual property rights]. Yntellektualnaia sobstvennost. Avtorskoe pravo y smezhnye prava, № 6, S. 70-71. [in Russian].

5. Kuvyrkova A.Yu. (2009) Licenzionnyj dogovor o predostavlenii prava ispolzovaniya obekta intellektualnyh smezhnyh prav [License agreement on granting the right to use the object of intellectual related rights]. Zakonodatelstvo, № 5, S. 58. [in Russian].

6. Melnyk O. (2003) Dohovory u sferi intelektualnoi vlasnosti za novym Tsyvilnym kodeksom Ukrainy [Intellectual property contracts under the new Civil Code of Ukraine]. Pidpryiemnytstvo, hospodarstvo ta pravo, № 9, S. 8. [in Ukrainian].

7. Dobrynina H. (2007) Litsenziina diialnist shchodo obiektiv prava intelektualnoi vlasnosti [Licensing activity towards intellectual property objects]. Spravochnik ekonomista, № 3. S. 5. [in Ukrainian].

8. Levchenko D. (2006) Aspekty licenzionnyh dogovorov. Otnositelno licenzionnyh dogovorov o peredache prav na obekty intellektualnoj sobstvennosti [Aspects of license agreements. On license agreements on the assignment of intellectual property rights]. Yurydycheskaia praktyka, № 11, S. 22. [in Russian].

9. Kyryliuk A.V. (2008) Litsenziinyi dohovir na vykorystannia literaturnykh tvoriv: poniattia, umovy, forma [License agreements on the use of literary writings: concept, conditions, form]. Aktualni problemy derzhavy $i$ prava, № 41, S. 192. [in Ukrainian].

10. Sorokyna L.V. (2008) Otgranichenie avtorskogo dogovora zakaza ot smezhnyh dogovorov [Delimitation of commissioning agreement from related agreements]. Rossyiskyi yurydycheskyi zhurnal, № 5, S. 204. [in Russian].

11.Zavalna Zh. (2002) Osoblyvosti dohovoru zamovlennia v avtorskomu pravi [Special aspects of an ordering agreement in copyright law]. Pidpryiemnytstvo, hospodarstvo i pravo, № 12, S. 15. [in Ukrainian].

12. Mamunia A. (2008) «Avtorstvo» v kommercheskom dogovore. Rasporyazhenie imushestvennymi pravami avtora $\mathrm{v}$ ramkah kompleksnogo soglasheniya ["Authorship" in the commercial contract. Disposal of property rights of the author under the framework of a complex agreement]. Yurydycheskaia praktyka, № 21 (543) ot 20.05 .08 h. // http://yurpractika.com. [in Russian].

13. Zhylynkova E. (2009) Klassifikaciya dogovorov v sfere realizacii imushestvennyh prav na obekty avtorskogo prava na Ukraine [Contracts classification in the area of intellectual property rights in Ukraine]. Yntellektualnaia sobstvennost. Avtorskoe pravo y smezhnye prava, № 1, S. 48. [in Russian].

14. Danevych B. (2009) Raspredelenie prav na avtorstvo. Problemnye aspekty raspredeleniya prav intellektualnoj sobstvennosti mezhdu rabotnikom 
i rabotodatelem [Allocation of author rights. Challenges of allocation of intellectual property rights between employee and employer]. Yurydycheskaia praktyka, 2009. № 39 (61) ot 29.09 .09 h. // http://yurpractika.com. [in Russian].

15. Klymenko A. (2004) Dogovor franchajzinga - analiz soderzhaniya [Franchise agreement - content analysis]. Nalohy y bukhhalterskyi uchët, № 74 (736) ot 13.09.2004, S. 25. [in Russian].

16. Biloshytskyi S. (2008) Modeli dohovoriv komertsiinoi kontsesii [Models of franchise agreement]. Pravovyi tyzhden, № 13 (86) vid 25.03.2008 r., S. 8. [in Ukrainian].

17. Leheida E. (1996) Franchaizynh. Novaia forma orhanyzatsyy byznesa [Franchising. A new form of business organization]. Byznes - ynform, № 20, S. 32. [in Russian].

Information about the author: Svitlana Mazurenko,

$\mathrm{PhD}$ in Law, Associated Professor at the Department of Intellectual Property Law, National University "Odessa Law Academy" 2, Academychna str., Odessa, 65009, Ukraine 